\title{
Some Features of Monolingual LSP Dictionaries
}

\author{
G.-R. Mihindou, Department of Afrikaans and Dutch, University of Stellen- \\ bosch, Stellenbosch, Republic of South Africa (guyr_mihindou@hotmail.com)
}

\begin{abstract}
Dictionaries are classified according to a certain set of criteria. On the one hand, there are general purpose dictionaries, aiming to satisfy the needs of the majority of users, and focused on the general vocabulary, and, on the other hand, there are limited or specific dictionaries for specialists dealing with language for special purposes (LSP). The type of dictionary dealing with technical and sometimes semi-technical vocabulary is compiled to satisfy the needs of those who already have a knowledge of a specific field but want to improve their skills. General purpose dictionaries are well known and users are relatively familiar with them, but it is not necessarily the case with LSP dictionaries. This type of dictionaries needs to be described or presented with emphasis on some of its features. As a result LSP dictionaries and general purpose dictionaries will often be compared.
\end{abstract}

Keywords: LSP DICTIONARY, GENERAL PURPOSE DICTIONARY, MEANING, TECHNICAL VOCABULARY, GENERAL VOCABULARY, USER NEEDS, DATA DISTRIBUTION, MACROSTRUCTURE, MICROSTRUCTURE, ORDERING TYPOLOGY

Opsomming: 'n Aantal kenmerke van eentalige TSD-woordeboeke. Woordeboeke word geklassifiseer volgens ' $n$ bepaalde stel kriteria. Aan die een kant is daar woordeboeke vir algemene doeleindes wat die behoeftes van die meerderheid gebruikers wil bevredig, en wat op die algemene woordeskat konsentreer, en, aan die ander kant, is daar beperkte of spesifieke woordeboeke vir vakkundiges wat taal vir spesiale doeleindes (TSD) behandel. Die soort woordeboek wat ' $n$ tegniese en somtyds semitegniese woordeskat behandel, word saamgestel om die behoeftes te bevredig van diegene wat reeds kennis van 'n spesifieke gebied besit, maar wat hul vaardighede wil verbeter. Woordeboeke vir algemene doeleindes is goed bekend en gebruikers is betreklik vertroud met hulle, maar dit is nie noodwendig die geval met TSD-woordeboeke nie. Hierdie woordeboeke moet omskryf of bekend gestel word met die klem op sekere van hul kenmerke. TSD-woordeboeke en woordeboeke vir algemene doeleindes sal gevolglik dikwels vergelyk word.

Sleutelwoorde: TSD-WOORDEBOEK, WOORDEBOEK VIR ALGEMENE DOELEINDES, BETEKENIS, TEGNIESE WOORDESKAT, ALGEMENE WOORDESKAT, GEBRUIKERSBEHOEFTES, DATAVERSPREIDING, MAKROSTRUKTUUR, ORDENINGSTIPOLOGIE

\section{Introduction}

Lexicography is commonly understood as the practice of dictionary-making. This implies the compilation and the preparation of reference texts for publica- 
tion. Therefore, an important product of lexicography is a dictionary or wordbook (Hartmann and James 1998) which treats many branches of knowledge. The term "dictionary" encompasses many genres or types, which can be structurally classified according to a certain set of criteria. In fact, dictionaries have often been classified in categories based on formal features, like size for example: pocket dictionary, abridged dictionary, concise dictionary, etc.

The major dictionaries in the market are classified according to their function in which the data play a vital role, and according to their intended role in satisfying the potential user's needs. The general purpose dictionary (GPD) for example will present the semantic data in such a way that any user can understand the "common" vocabulary. The restricted dictionary is a special or specialized dictionary focusing on specific users who may be experts, semi-experts or non-experts. That is why Hartmann and James (1998) assert that a functional typology or categorization based on the contextual uses of dictionaries should focus on data types or categories. This article deals with the last category or type of dictionary which focuses on Language for Special Purposes (LSP). The LSP dictionary (LSPD) is a type of dictionary which aims to satisfy the needs of a specific group of users. Gouws (2000: 10) concedes that there is no single dictionary which can be everything to everybody; consequently a specialized dictionary has a very important role to play.

This implies that such a specialized dictionary will present the data in different ways, also treating and presenting the comment on semantics differently. The aim of this article is to analyse some aspects of the treatment and presentation of meaning in LSP dictionaries and their structures. The accent will mostly be on monolingual LSP dictionaries. But firstly a brief discussion of LSP dictionaries will be given.

\section{The LSP Dictionary}

In a strict sense, an LSP dictionary is a type of reference work intended to describe language variety used by experts in a particular subject field (Hartmann and James 1998). In a general sense, the LSP dictionary is part of the so-called restricted dictionaries (Burkhanov 1998), special dictionaries (Singh 1982) or technical dictionaries (Hartmann and James 1998). The term "restricted dictionary", according to Burkhanov (1998: 201), is used with reference to a large and heterogeneous group of dictionaries, starting from phraseological dictionaries via terminological and dialect dictionaries to hard word dictionaries. The term "restricted" does not necessarily imply a shorter or smaller size of work, because some restricted dictionaries are quite large. More so, the LSPD can rightly be considered a technical dictionary (Hartmann and James 1998).

By "technical" two kinds of dictionaries must be understood. On the one hand, there is the dictionary which deals with the very technical vocabulary of a specialized subject discipline. The objectives of such a type of dictionary are to satisfy and inform the experts. In fact, professionals in several specialized 
fields defend their use of technical and complex language as being the most precise means of expressing technical and complex ideas. Therefore, the evidence is that scientists, doctors, bankers, and others need their jargon in order to communicate with each other succinctly and unambiguously (Crystal 1997: 383). As a result, this type of dictionary is conceived as an aid for users who are already specialists in their field, but want to acquire more skills. On the other hand, it can be a dictionary which considers experts, semi-experts and laypersons as users. In such a dictionary, the vocabulary will be semi-technical. So, as far as the semi-technical dictionary is concerned, there are no theoretical limits to the number of special purposes to which language can be put (Crystal 1997). Recently whole new areas of technical expression have emerged, concerning such domains as computing, broadcasting, commercial advertising and popular music. The lexicographer should therefore include the average user's knowledge needs in these semi-technical LSPDs.

According to Smit (1996: 142), Wiegand (1983: 116) says that the many statements in a general theory of lexicography can be formulated with relation to dictionary typology. As far as the LSPD is concerned, it is relevant to follow both the different typological criteria suggested by Wiegand (1983: 104), based on the purpose of and the language use in dictionaries.

The first suggestion determines the specific structure of a given lexicographic work. The second suggestion deals with the nature of the language currently treated in a dictionary. Here, according to his needs, the potential user becomes the key person in determining the type of language to be used in a dictionary. In this way, Wiegand (1983: 111) explains the theory of lexicographic language description, focusing on the set of eventual questions from the potential users and the different answers the lexicographer wants to develop as an input to a dictionary. Therefore the answers oriented at the potential users will play an important role in determining the type of dictionary.

In the same way, a special-field dictionary will be a dictionary dealing with a specific field and the potential user of this type of dictionary will ask particular questions or will express specific needs, which will guide the compiler. Once the potential users have been identified, their needs will influence the typology of the dictionary and the decisions of the lexicographer. The title of a dictionary indicates which kind of field and part of knowledge the text work covers, the type of lemmata, the structure of lexical items, etc.

\section{The LSP Dictionary and the General Purpose Dictionary}

An LSPD is very often opposed to a GPD. The GPD deals with the "commonest", the general vocabulary. But the LSPD treats a specific and precise vocabulary. Singh (1982: 18) observes that general dictionaries contain those words of the language which are in general use representing various spheres of life and presenting a complete picture of the general language. Special diction- 
aries either cover a specific part of the vocabulary or are prepared for some definite purpose.

In the same light, Burkhanov (1998) asserts that GPDs are meant to represent the general vocabulary; they are mainly concerned with that part of the lexicon not restricted to a particular style or register. Lexical items, for instance, belonging to the regional and social varieties of a language, as well as the specialized terminology of particular academic disciplines and various subject fields, are not supposed to be included in the word list of a GPD. In some cases, however, they are included, but then provided with a label.

The expectations of the GPD user are very often aimed at some lexicographic data types such as grammatical information, pronunciation, peculiarities of spelling, etc. In this way, the GPD is closer to the expectations of the ordinary user. The LSPD, on the contrary, may account for only one lexicographic parameter, for instance dealing with only one aspect of lexical items or one type of semantic relation between those lexical items. Therefore, the dictionary of homonyms can serve as an example. LSPDs as technical dictionaries are governed by one common principle, namely to be non-ambiguous.

Van Schalkwyk (1987) maintains that it is important to keep in mind that a technical term should have only one logical and unambiguous meaning. This can be considered as the most precise aspect in the treatment of lexical items in LSPDs. Therefore, the consequence of making a comparison between an LSPD and a GPD leads the metalexicographer into another comparison between specialized lexicography, regarded as more prescriptive, and general lexicography, considered as more descriptive.

\begin{tabular}{|l|l|}
\hline GENERAL LEXICOGRAPHY & LIMITED/RESTRICTED LEXICOGRAPHY \\
\hline General vocabulary & $\begin{array}{l}\text { Regional and social/specialized vocabu- } \\
\text { lary }\end{array}$ \\
\hline Deals with a nonrestricted lexicon & $\begin{array}{l}\text { Deals with a restricted lexicon and particu- } \\
\text { lar register }\end{array}$ \\
\hline $\begin{array}{l}\text { Encompasses lexical items of linguistic } \\
\text { usage }\end{array}$ & Concerned with specific terminology \\
\hline $\begin{array}{l}\text { Describes usages understood and accepted } \\
\text { by all native speakers of a given language }\end{array}$ & $\begin{array}{l}\text { Describes localized or specific usages ob- } \\
\text { tained by convention for selected speakers. }\end{array}$ \\
\hline $\begin{array}{l}\text { Expected to provide lexicographic infor- } \\
\text { mation }\end{array}$ & $\begin{array}{l}\text { Expected to furnish lexicographic descrip- } \\
\text { tion }\end{array}$ \\
\hline $\begin{array}{l}\text { Various linguistic parameters of lexical } \\
\text { items in the central list }\end{array}$ & $\begin{array}{l}\text { Only one type of semantic relation be- } \\
\text { tween lexical items in the central list }\end{array}$ \\
\hline $\begin{array}{l}\text { Example of parameters: explanation of } \\
\text { meaning, grammatical information, par- } \\
\text { ticularities of spelling }\end{array}$ & $\begin{array}{l}\text { Example of parameters: inflectional or } \\
\text { derivational proprieties of lexical items, } \\
\text { synonymy, antonymy }\end{array}$ \\
\hline
\end{tabular}

Source: Burkhanov (1998)

It is also important to make a distinction between limited/restricted dictionaries and LSP/specialized dictionaries. 


\begin{tabular}{|l|l|}
\hline LIMITED/RESTRICTED DICTIONARIES & LSP/SPECIALIZED DICTIONARIES \\
\hline $\begin{array}{l}\text { Refer to a large and heterogeneous group } \\
\text { of philological dictionaries }\end{array}$ & $\begin{array}{l}\text { Refer to lexicographic works for linguistic } \\
\text { and non-linguistic aspects of specialized } \\
\text { terminologies }\end{array}$ \\
\hline $\begin{array}{l}\text { Regional and social varieties of language } \\
\text { as well as specialized terminology of a spe- } \\
\text { cific subject field }\end{array}$ & $\begin{array}{l}\text { Specialized terminology of a specific sub- } \\
\text { ject field only }\end{array}$ \\
\hline Multi-field and single field terminology & Multi-field and single field terminology \\
\hline Limited to a particular style or register & $\begin{array}{l}\text { Focus on scientific and technical vocabu- } \\
\text { lary }\end{array}$ \\
\hline $\begin{array}{l}\text { Restriction imposed on the selection of } \\
\text { lexical items }\end{array}$ & $\begin{array}{l}\text { Restriction imposed on the selection of } \\
\text { lexical items }\end{array}$ \\
\hline $\begin{array}{l}\text { Examples of dictionaries: phraseological, } \\
\text { pronunciation, terminological dictionaries, } \\
\text { etc. }\end{array}$ & $\begin{array}{l}\text { Examples of dictionaries: terminological, } \\
\text { technical, translation dictionaries, etc. }\end{array}$ \\
\hline
\end{tabular}

Source: Hartmann (1983)

The distinction between these two categories of dictionaries can be illustrated as follows: The Dictionary of 1000 French Proverbs will fall under restricted dictionaries because of its limited register, The Oxford Concise Dictionary of Linguistics will be included under LSP dictionaries due to the specialization of the field it presents.

Svensén (1993: 2) who supports the assertion made by Geeraerts (1987) says, "The difference between general and technical dictionaries is not just a matter of selection. The methods of description and explanation are also different. A definition of concepts in a technical dictionary is often more detailed than that of the same concept in a general dictionary."

Hartmann and James (1998) attempt a classification based on general reference work vs. specialized reference work, as well as linguistic information vs. factual information.

\begin{tabular}{|l|l|l|l|}
\hline \multicolumn{2}{|c|}{ GENERAL } & \multicolumn{2}{c|}{ SPECIALIZED } \\
\hline Linguistic information & Factual information & Linguistic information & Factual information \\
\hline General Dict. & Encyclopaedia & Dict. of Foreignisms & Dict. of Music \\
\hline Learner's Dict. & Almanac & Dict. of Idioms & Dict. of Medicine \\
\hline Historical Dict. & Companion & Dict. of Archaisms & Dict. of History \\
\hline Bilingual Dict. & Biographical Dict. & Dict. of Proverbs & Dict. of Law \\
\hline Dict. of Names & Directory & Dict. of Quotations & Dict. of Botany \\
\hline Spelling Dict. & Catalogue & Dict. of Allusions & Dict. of Geology \\
\hline Pronouncing Dict. & Bibliography & Dict. of Confusibles & Dict. of Chemistry \\
\hline User guide & Compendium & Dict. of Slang & Dict. of Art \\
\hline Dialect Dict. & Travel Guide & Dict. of Neologisms & Dict. of Physics \\
\hline Thesaurus & Atlas & Dict. of Jargon & Term Bank \\
\hline
\end{tabular}

Source: Hartmann and James (1998) 
This classification confirms the assertion by Gouws (2000: 11) on the risk of confusion between sets of reference works and therefore the pertinence of criteria used for any attempt at classification. The bilingual dictionary, for instance, considered as part of general reference works could also be classified among the specialized reference works. There are some bilingual dictionaries focusing on languages such as English and Afrikaans as well as other bilingual dictionaries dealing with special fields such as medicine, botany or scientific terms generally. The fact that linguistic information and factual information as criteria of classification are presented in both general lexicography and specialized lexicography indicates a possible hybridization for both lexicographic categories.

The viewpoint of Wiegand about special-field dictionary typology is presented in detail by Smit (2000: 174-177). Wiegand (1998: 742) refutes any classification on the dichotomy between language dictionaries and encyclopaedias based on the distinction semantic items vs. encyclopaedic items. He rather suggests a classification of reference works focusing on what he calls the genuine purposes of a reference work. Regarding the genuine purpose of a special-field dictionary, Wiegand (1994: 105) stipulates that it is an object used to obtain information that may be considered as special-field knowledge. Wiegand (1998) is also in favour of the idea that reference works should be grouped in two distinct classes: the first, K1, will be the class of linguistic objects whereas the second, K2 will therefore be the class of non-linguistic objects or "things"; $\mathrm{K} 2$ being the class of all reference works with a genuine subject-lexicographic purpose.

From the above discussion, it becomes clear that it is difficult to classify dictionaries very strictly. The chances are good that one set of criteria is considered and others are neglected. The languages themselves do not obey such rigid categorisation. Furthermore, the borders between categories are unclear. Gouws (2000: 11) rightly says that the differences between two neighbouring categories are often so few that a specific dictionary could be placed in either category. Svensén (1993: 21) confirms this, saying, "The distinction between general and technical dictionaries can often be difficult to define. In general terms, purely technical dictionaries are commoner than purely general dictionaries." Regarding differences between general and technical dictionaries, some classifications may be made. Therefore, Al-Kasimi (1977) proposes that dictionaries can be classified in various ways according to their range, perspective, purpose, and presentation. In this article, two types of LSPDs have been retained and adapted, based on the proposition of Singh (1982).

(a) Dictionaries of technical terms: They deal with technical terms in a language, and, as has been said above, terminology plays the most dominant and vital role in this type of dictionaries. They are focused on special fields in life, and are often presented by special bodies and commissions formed especially for that purpose. They contain either terms peculiar to a particular subject field or general words with special mean- 
ings for special fields. A dictionary of lexicography, a dictionary of medical terms, a dictionary of linguistics, etc., can serve as illustrative examples.

(b) Dictionaries of special professions: These dictionaries present lexical items in a particular way according to the professional jargon. A dictionary of antiques and decorative arts, a reference book for glass collectibles, a dictionary of technical terms containing definitions of commonly used expressions in aeronautics, etc., can be considered as examples of these.

To summarize what has been said above concerning the LSPD, the following points should be kept in mind: Firstly, this type of dictionary depends totally on the aspects of the language covered. Secondly, it can be limited to one aspect of the language. And thirdly, this kind of dictionary deals with only one logical and unambiguous meaning.

\section{Meaning in the LSP Dictionary}

As has been said in the introduction, the aim of this article is to present some aspects of the treatment of meaning in the LSPD. Users consult a dictionary primarily to establish and understand the meaning of a lexical item. According to the quality of a text work, the meaning of one lexical item can have a more or less specific treatment in a dictionary. The treatment of meaning is determined on the one hand by the needs of the user, and on the other hand by the goals the lexicographer wants to achieve. Burkhanov (1998: 148) sees in meaning the major part of linguistic semantics and lexicological study, an important concept for lexicographic description of the lexicon and a possibility for making a considerable impact on the final lexicographic product.

Semantic data is presented in the dictionary in many ways. One of these is the description of meaning or the lexicographic definition. Here, the definition consists of a definiendum and a definiens. The definiendum is a lemma, the term or the word, which the lexicographer wants to explain in the dictionary article, whereas the definiens is the explanation of the meaning. Many lexicographers use the term "description of meaning" or "lexicographic definition of meaning". Wiegand (1992) prefers the term "paraphrase of meaning".

The lexicographer uses different methods to describe and to identify the meaning of a lexical item. According to Gouws (2000), not all lemmata can be defined in the same way and lexicographers rely on different types of definitions in the process of explaining meaning. Therefore, four different types of definitions are frequently used, namely:

(a) The generally descriptive definition in which the meaning of the definiendum is explained by the definiens without any reference to the seman- 
tic relationship between the definiendum and other lexical items. Monolingual LSPDs often use this category of the explanation of meaning.

(b) The genus-differentia definition which does not only explain the meaning of the lemma, but also places the lemma in a class (genus) and operates by distinguishing through opposition between the lemma and other members of the class. In the context of explanations of meaning, this category is especially used in monolingual LSPDs.

(c) The synonym definition which gives a synonym for the lemma. This category is used in LSPDs, especially in the context of translation equivalents in the target language.

(d) The circular definition which implies a very strong resemblance between the definiendum and definiens.

All these different mechanisms employed by the lexicographer to describe, explain, and identify the meaning should be presented as clearly as possible if he wants to see his dictionary used successfully.

When the lexicographer speaks about meaning, he is dealing with more than a simple understanding of an idea. Words, references, symbols, and mental content are involved. It is almost impossible to speak about meaning in a dictionary without the word supporting this meaning. So meaning and word are intimately linked but not necessarily fused. The word the lexicographer includes as lexical item in a dictionary, like, for instance, a dictionary of econometrics, is a sum of symbols linked together in a way to be pronounced as one unit and interpreted in a certain way. This interpretation brings out the meaning. The process of this operation implies certain mechanisms in the mind of the user and the compiler.

As a result, one word can have one, or more than one, meaning. Therefore the lexicographer will be able to treat the lemma in an appropriate way according to the context or the co-text. He can, for instance, treat a lemma in such a way that the differentiations between denotation and connotation will be clear to the user and will indicate at the same time relations of meaning such as synonymy, antonymy, hyponymy, etc. This point will be illustrated in the examples below from an LSPD as a technical dictionary.

By a technical dictionary should be understood two types of dictionaries. On the one hand, there is the technical dictionary for experts, the terminological dictionary (Hartmann and James 1998) in which the emphasis is on expert knowledge, which implies the description of scientific and technical words in a certain field in a precise and specialized way. On the other hand, there is the LSP dictionary intended as a text work containing a semi-technical vocabulary, intended for relative neophytes or advanced learners (Hartmann 1998: 136).

As a technical dictionary the LSP dictionary uses a technical language when it refers to a specific register of the language dealing with a more or less 
hermetic vocabulary and meanings as well. For example, a lexical item such as absence has different meanings, depending on the type of dictionary. The Longman Dictionary of the English Language defines the word as follows:

absence /'absəns / $n \mathbf{1}$ the state of being absent ... 2 the period of time that one is absent 3 a want, lack $\langle$ an $\sim$ of detail $\rangle$

absence of mind $n$ inattention to present surroundings or occurrences

In The New Shorter Oxford English Dictionary the following definition is presented:

absence /'abs(ə)ns / ... n . 1 The state of being away from a place or person; the time or duration of being away. ... 2 Non-existence or lack of. ... 3 Inattention due to thinking of other things. Esp. in absence of mind. $\mathbf{b}$ Med. Sudden temporary loss of consciousness occurring without the awareness of the subject, esp. in petit mal; an episode of this (also absence seizure)....

Both these dictionaries are considered as GPDs. The definiens, i.e. the explanation of the meaning, has been presented in such a way that "any" dictionary user can recognize and comprehend it as belonging to the general or common vocabulary. It therefore shows that in a GPD the emphasis is on the presentation or the treatment of the "ordinary" meaning of lexical items encompassing a general view.

Bell's South African Legal Dictionary, however, approaches absence differently:

ABSENCE, as a ground for relief under the Insolvency Act, No. 32 of 1916, means absence from the country; that is, from the Union and not merely from one Province thereof (Estate Elaides v. Sackville Clothing Co. and another, 1925 W.L.D. 144).

In Black's Law Dictionary absence is defined as follows:

absence, $n$. 1. The state of being away from one's usual place of residence. 2. A failure to appear when expected.

These dictionaries may be considered technical dictionaries because of their very restrictive approach in terms of macrostructural selection and treatment. This restrictive approach may be balanced by bringing a semi-technical view of the lexical item absence, explained to both expert and neophyte dictionary users.

Stroud's Judicial Dictionary of Words and Phrases describes five different contexts of use:

ABSENCE. (1) Judicial separation obtained in the "absence" of the respondent (Matrimonial Causes Act 1857 (c. 85), s. 23) meant his or her non-appearance in the suit (Phillips v. Phillips. L.R. 1 P. \& D. 169)....

(2) Absence of seaman without leave: defined in Merchant Shipping Act 1894 (c. 60), s. 376 (1)(b), as "neglecting or refusing without reasonable excuse, to join or to proceed to sea in his fishing boat, or being absent without leave at 
any time within 24 hours of his boat's sailing from any port, either at the commencement or during the progress of the engagement, or being absent at any time without leave and without sufficient reason from his boat": see Edgill v. Alward [1902] 2 K.B. 239, cited WiLful DisObEDiENCE. ...

(3) "Absence" (Matrimonial Causes Act 1950 (c. 25), s. 14 (3)) means "physical absence" and not "non-appearance". The fact that a party has entered a limited appearance does not preclude the operation of the section (Wilkinson v. Wilkinson [1963] P. 1).

(4) "Absence at any school" (Family Allowances Act 1945 (c. 41), s. 21 (7)) does not include being taken into care by a local authority in one of its own schools, where there is no going home for the holidays (Hill v. Minister of Pensions and National Insurance [1955] 1 W.L.R. 899).

(5) "Absence without leave." Stat. Def., Army Reserve Act 1950 (c. 32), s. 28 (1); Air Force Reserve Act 1950 (c. 33), s. 27 (1).

Osborn's Concise Law Dictionary, however, explains the lexical item absence in a very short and simple definiens as follows:

\footnotetext{
Absence. If a person has not been heard of for seven years, and the circumstances are such that, if alive, he would have been heard of, the presumption of death arises, but not as to the date of death (Re Phene's Trusts (1969) L.R. 5 Ch. App. 139). The court may, however, order that death be presumed at any time if sufficient evidence is shown. See the Matrimonial Causes Act 1973, s. 19; Domicile and Matrimonial Proceedings Act 1973, Sched. 6. ...
}

The definitions of absence given in the two GPDs, namely the Longman Dictionary of the English Language and The New Shorter Oxford English Dictionary can now be reconsidered. In the first, the lemma has been treated as a polysemous word, differentiating three senses which occur in general usage. In the second, the treatment of meaning is presented in such a way that the user can quickly distinguish two different components. Firstly, the lemma is shown to be a polysemous word, and, secondly, the lemma has been labelled. An explanation is given according to common usage, employing the general vocabulary to explain the word in three different senses. An explanation of the word used in a specialized field, labelled Med., i.e. in medicine, is also presented. As this specialized meaning differs from the use of absence in the general language, the context and field in which it is used must be indicated.

For LSPDs the approach is somewhat different, as can be seen from the definitions in the four technical dictionaries, namely Bell's South African Legal Dictionary, Black's Law Dictionary, Stroud's Judicial Dictionary of Words and Phrases, and Osborn's Concise Law Dictionary. These all give senses of absence as used in the legal parlance. Stroud's Judicial Dictionary of Words and Phrases, for instance, does not use labelling like that in The New Shorter Oxford English Dictionary. It develops the lexical item in five different senses which are all essentially focused on the field of law. The explanations are of use to specialists of law only. There are, for example, many quotations dealing with laws, like the 
Matrimonial Causes Act, the Family Allowances Act, etc. These reference texts and the vocabulary within them are not for ordinary but for knowledgeable users. In this type of dictionary, the emphasis is not so much on the understanding of the item itself, but on the different contexts covered by the judicial concept of absence, because it is assumed that lawyers already have knowledge of the "ordinary meaning".

\section{Structure of the LSP Dictionary}

\section{Data distribution and user needs}

Most dictionaries depend on the nature and the extent of the data, especially from the viewpoint of the users' needs. Dictionaries are classified according to certain criteria first established by the metalexicographer. Before the compilation of a dictionary, the metalexicographer has to play an important role in planning the process of the dictionary. In this connection Lombard (2000) says:

It is very important for the lexicographer to know who the target users of his labours are going to be before work on the dictionary can begin. Because the character of a dictionary and the nature of the material presented in it should be determined by who the target users are, one of the most important tasks of the compiler of any dictionary is to make the product user-friendly. User-friendliness thus becomes one of the criteria in terms of which a dictionary is assessed.

Lexicographers should consider the users' needs in order to establish the dictionary classification even if there is no entirely satisfactory method of classification.

Data plays an important role in the LSPD; it gives consistency to the dictionary and determines which lexical items will be included and which will be omitted. Raw material, data, once collected, will indicate the configuration of the future dictionary. In this case, the purpose of the LSPD is to serve users who already have knowledge of the field; the focus will be on the real needs of the users. In a dictionary of medical terms, for instance, the field is medicine, the potential users are doctors and specialists dealing with this discipline. The metalexicographer is supposed to focus the attention on the users and their needs. The compiler must also consider that in an LSPD focusing, for instance, on medical terms, certain types of users like students in medicine are semiexperts or semi-specialists, who must be enabled to retrieve the information they are looking for. One of the responsibilities of the compiler is to select data and treat it in such a way that the LSPD will satisfy both types of users: experts and non-experts.

When the definitions of absence in the four legal dictionaries are compared, it will be seen that those in Black's Law Dictionary are less specialized than those in the other three, namely Bell's South African Legal Dictionary, Osborn's Concise Law Dictionary, and Stroud's Judicial Dictionary of Words and Phrases. They al- 
most equal those in GPDs. This indicates that these dictionaries are meant for different user groups.

Tarp (2000: 194) concedes that when a lexicographer conceives or produces a dictionary he has at least always a target group of users in mind, be they homogenous or heterogeneous, otherwise it will be difficult to establish a proper lexicographic work based on scientific principles. One of these principles is the obligation for the compiler to know the users' competencies in the subject field in which the LSPD is going to be compiled. The main question will then be: At what level of mastering the special subject field in question are the users?

From the knowledge of a specific discipline, other criteria based on the linguistic performances of the users should be added, such as:

- At what level have they mastered the corresponding LSP in their mother tongue?

- At what level have they mastered the corresponding LSP in a foreign language?

The first point is particularly important in the case of monolingual LSP dictionaries, the second point in the case of bilingual LSP dictionaries.

\section{Macrostructure}

The macrostructure of an LSPD is not too different from that of other dictionaries in terms of theory, because they all obey several criteria of metalexicography. But the term "macrostructure" covers two different aspects: one which is concrete, and the other which is abstract. So, on the one side, a dictionary presents several sections within which any user can identify a number of dictionary components such as the lemmas, to which other entries are directed. But this arrangement comes from another part of the structure, which is known as the data distribution structure or data distribution programme in which every detail present in the dictionary has been discussed and planned by a team of metalexicographers. This data distribution structure is the only one which can give the most concise and precise configuration of the future dictionary. In an LSPD, this data distribution structure will clearly offer the real intention of the compiler and the real user, and even anticipate and decide which kind of needs the user has. This structure guides the metalexicographer, lexicographer and all specialists interested in how a dictionary has been compiled and what procedure has been followed.

In macrostructural perspective, the structural skeleton of an LSPD basically has the same ordering as GPDs. There are, for instance, two major components in a given dictionary article: comment on form and comment on semantics. The first is considered part of the macrostructural procedure whereas the 
second is classified as part of the microstructural treatment. However, LSPDs present fewer entries than GPDs, for example as far as labelling is concerned. The following example taken from Stedman's Medical Dictionary can be considered:

hermetic (her-met'ik). Airtight; denoting a vessel closed or sealed in such a way that air can neither enter it nor issue from it.

In a normal GPD, this lexical item would have been treated differently. Apart from the phonetic markings, morphological features would have been included as well as grammatical information such as the part of speech as can be seen in the following definitions from Chambers 21st Century Dictionary and The New Oxford Illustrated Dictionary.

hermetic/h3:'metik/ and hermetical $\triangleright$ adj. 1 perfectly closed or sealed so as to be airtight. 2 belonging or relating to magic or alchemy. 3 obscure or abstruse. - hermetically adverb. • hermeticity |h3:'mə'tIsItI| noun. (1) 17c: named after Hermes Trismegistos, supposedly the Greek author of texts on magic and alchemy, and also the inventor of a magic seal.

hermě'tic adj. Of Hermes Trismegistus; of alchemy, magical, alchemical; seal, sealing, airtight closure of vessel, esp. glass vessel, by fusion, soldering, or welding.

hermě'tǐcally̆ $a d v$.

In the Chambers 21st Century Dictionary, the lemma hermetic is followed by a phonetic transcription, /hs:'metIk/, an additional headword hermetical as morphological variation, indicating an optional choice offered to the user, then the symbol $\triangleright$ used to mark the principal part of speech, in this case adj. written in italics. The New Oxford Illustrated Dictionary offers slightly less information: The phonetic information forms part of the lemma herměttic, followed by the part of speech adj. in italics. In macrostructural perspective, this information may be considered important, and may be useful in GPDs but not necessarily in an LSPD like Stedman's Medical Dictionary, the focus here being mainly orientated towards the genuine interpretation of the meaning of the lexical item hermetic in the particular context of medicine.

The Chambers Dictionary with a more comprehensive perspective presents its article as follows:

hermetic hûr-met'ik or hermetical -met'ik-l, adj belonging in any way to the beliefs current in the Middle Ages under the name of Hermes, the Thrice Great; belonging to the magic or alchemy, magical; perfectly closed, completely sealed; obscure, abstruse. - adv hermet'ically. $-n$ hermetic'ity - $n$ sing hermet'ics the philosophy contained in the hermetic books, esoteric science; alchemy. - hermetically sealed closed completely; made airtight by melting the glass. [Medieval L hermêticus, from Hermēs Trismegistos Hermes the thrice-greatest, the Greek name for the Egyptian Thoth, god of science, esp alchemy] 
With regard to the dictionary articles of hermetic cited above, it becomes clear that the treatment of meanings, and therefore the purpose of GPDs and LSPDs differs: In the medical dictionary, the lexicographer has included only the essential data, just enough to capture the meaning and define its medical use. In the GPDs, more details are given. Moreover, this comparison shows that what is hierarchically positioned as denotation (of first importance) in an LSP, might be connotation (of second importance) in a GPD.

\section{Ordering typology}

Like GPDs, LSPDs often present their lemmata in alphabetical order. In the example of hermetic from The Chambers Dictionary, "hermetically", "hermecity", "hermectics", "hermetic books", "hermetically sealed" are all presented as sublemmata of the lexical item hermetic. This can be compared to the first part of the example of hernia from Stedman's Medical Dictionary:

hernia (her'nē-ă) [L. rupture] Rupture (1); protrusion of a part or structure through the tissues normally containing it.

abdominal h., laparocele; a h. protruding through or into any part of the abdominal wall.

antevesical h., an interstitial $h$. projecting medially from the internal inguinal ring.

Barth's h., a loop of intestine between a persistent vitelline duct and the abdominal wall.

Béclard's h., a h. through the opening for the saphenous vein.

bilocular femoral h., Cooper's $h$.

h. en bissac, properitoneal inguinal $\mathrm{h}$.

Bochdalek's h., congenital diaphragmatic $h$.

h. of the broad ligament of the uterus, a coil of intestine contained in a pouch projecting into the substance of the broad ligament.

cecal h., a h. containing cecum.

cerebral h., protrusion of brain substance through a defect in the skull.

Cloquet's h., a femoral h. perforating the aponeurosis of the pectineus and insinuating itself between this aponeurosis and the muscle, lying therefore behind the femoral vessels.

complete $\mathbf{h}$., an indirect inguinal $h$. in which the contents extend into the tunica vaginalis.

concealed $\mathbf{h}$., a h. not found on inspection or palpation.

congenital diaphragmatic $\mathbf{h}$. , Bochdaleck's h.; absence of the pleuroperitioneal membrane (usually on the left) or an enlarged foramen of Morgagni which allows protrusion of abdominal viscera into the chest.

The alphabetical ordering of The Chambers Dictionary as GPD is based on a word-by-word arrangement, whereas Stedman's Medical Dictionary as LSPD combines both alphabetical and thematic ordering in a single article. The lemma hernia is used here as an umbrella under which all types of hernia are treated 
despite their alphabetical order. The thematic ordering is mostly used in LSPDs and rarely in GPDs.

The ordering typology can be summarized as follows: In GPDs the central list is established in alphabetical order, which implies that the lemmata, sublemmata, and even article stretches are arranged from A to Z. But LSPDs can present other arrangements according to the purposes decided on in the data distribution programme. It can be an alphabetic, thematic, or semantic ordering.

In a thematic ordering, lexical items are grouped in families or genera. Items such as beauty, elegance and peace can be grouped in a category human being, while words such as cholera, AIDS, and malaria can be incorporated in a disease category.

The semantic ordering is more often used in a synonym dictionary; terms are arranged according to the field and a concept covered by the lexical items. In these types of dictionaries, the treatment consists of a listing of a paradigm of synonyms. As a result, the dominant term is chosen as lemma and the other terms become synonyms, always arranged according to the semantic aspects of the lexical items.

\section{Microstructure}

In this section, it will be shown how the treatment of a given lexical item differs in different types of dictionaries. As a technical dictionary, the LSPD uses "technical" language when it refers to a specific register of the language dealing with a more or less hermetic vocabulary as well as its meanings. For example, a lexical item like absence has, as has already been shown above, different meanings, depending on the type of dictionary. Once more the different definitions of absence proposed by the Longman Dictionary of the English Language and The New Shorter Oxford English Dictionary can be considered.

The first dictionary treats the lemma by means of three definitions, the purpose being to give explanations of the lexical item absence in such a way that the user can easily retrieve "good" information. But if this treatment is observed carefully, it appears that the three definitions and senses combined in this article all refer to an adjective or a noun which should be explained somewhere else in the dictionary for a complete understanding. The definitions/senses 1 and 2, for instance, define absence in terms of the adjective absent. In this particular case, the user cannot understand the meaning of absence if he/she does not know what the adjective absent means. To understand definition/sense 3 the user must know the meaning of the nouns want and lack. This type of definition results in a so-called "circular definition".

The second dictionary also gives three definitions/senses. Sense $\mathbf{1}$ is defined by means of a direct meaning description without reference to the adjective absent. In sense 2, the user must also, as in the first dictionary, be acquainted with the meanings of two nouns, namely nonexistence and lack. Moreover, it combines these direct meanings with transferred meanings in sense 3, 
referring to a state of someone whose thought/mind is not present. This usage of absence is a transposition of the sense by analogy.

As has been said above, three of the four legal dictionaries which can be considered technical (or LSP) dictionaries, namely Bell's South African Legal Dictionary, Stroud's Judicial Dictionary of Words and Phrases and Osborn's Concise Law Dictionary, explore the meaning of the lexical item absence in a very strict and specific way. To understand the meaning of absence in Bell's South African Legal Dictionary for instance, the user needs first to know to what "the Insolvency Act, No. 32 of 1916" refers. This necessitates a certain legal background. It implies that for the compilers of these dictionaries, the user is expected to have a certain legal knowledge, which can help him/her to appreciate the relevancy of these meaning descriptions. As a result, only users who are legal specialists will, in this case, obtain enough "good" information from Bell's South African Legal Dictionary. This restrictive approach may be broadened by bringing a somewhat semi-technical view of the lexical item absence, providing explanations for users who are both experts and neophytes.

Of all the technical dictionaries mentioned above, Osborn's Concise Law Dictionary especially offers a more accessible meaning description of absence than those of the other two: Bell's South African Legal Dictionary and Stroud's Judicial Dictionary of Words and Phrases. Its explanation summarized in one dictionary article, is both accurate and simple. It encompasses the legal time and circumstance which precede the declaration of absence as well as the legal procedure attached to it. This implies that in terms of user perspective, qualified lawyers, law students and neophytes can easily and quickly retrieve the information for which they are looking. In this sense, the given description of meaning is more specific. It can be assumed that the meaning of absence as presented in the GPDs, the Longman Dictionary of the English Language and The New Shorter Oxford English Dictionary, is already known to the users consulting the legal dictionaries.

\section{Access structures}

In many GPDs, data is presented to users according to certain priorities set up in advance by the lexicographer in order to satisfy their needs. This is also the case with LSPDs. Some aspects such as the degree of expertise in a given discipline, the level of the language used in the data, as well as the scale of accuracy in the treatment of meaning in a given dictionary are factors generally influencing the process of compilation, shaping the form of the lexicographic work and opening a way to satisfying the dictionary user.

Because technical terms designate a distinct concept, they have a nominating and a defining function. As a result, they are expected, as is suggested by Gläser (2000: 88), to be precise, unequivocal, unemotional, stylistically neutral, without evaluative connotations, and suitable for patterns of word-formation. 
According to Bergenholtz, Tarp and Wiegand (1999), a distinction can be made between a simple data distribution structure focusing only on articles in the central list of a dictionary and an expanded data distribution focusing on the outer texts of a dictionary or some of these. In this article, with regard to examples of dictionary articles given below, only the first one (simple structure) is taken into account. Despite the user-driven approach, LSPDs are also dictionary-function orientated. Two functions can be distinguished (cf. Bergenholtz and Tarp 1995: 20-28):

(a) communication-directed functions, which aim to assist the user in solving problems in the sphere of communication (cf. Gouws (2002: 56), as is the case with the lemma heart from The Oxford Medical Companion:

HEART. The heart is the muscular pump which maintains circulation of the blood, situated in the thorax to the left of the midline. The right and left sides are separate functional units, each comprising a filling chamber, or atrium, and a much thicker and more muscular ventricle. The side receives deoxygenated venous blood returning from the tissues and pumps it into the lungs via the *pulmonary arteries. From here, after oxygenation by pulmonary ventilation, it returns to the left side and is pumped by the ventricle back into the tissues via the *aorta and the *arteries.

This treatment of the lexical item heart includes in the definition references to definitions of concepts related to the lemma heart, e.g. aorta and arteries.

(b) knowledge-directed functions which intend to increase the user's knowledge with regard to a specific topic, as illustrated by the lemma heart from Taber's Cyclopedic Medical Dictionary:

heart (hart) [AS. heorte]. A hollow, muscular, contractile organ, the center of the circulatory system. Its wall possesses three layers: the outer epicardium, a serous layer; the middle myocardium, composed of cardiac muscle; and the inner endocardium, a layer which lines the four chambers of the heart and covers the valves. The heart is enclosed in a fibroserous sac, the pericardium, the space between the pericardium and the epicardium forming the pericardial cavity. SEE: circulation for illus.

This treatment of the lexical item heart includes in the definition comments and descriptions of various concepts related to the lemma heart, notably epicardium, myocardium, endocardium and pericardium.

In LSPDs, articles with definitions conveying cultural and historical information are also included, as can be seen from the following examples from The Oxford Medical Companion:

COS (now Kos), is an island in the Dodecanese, near the shores of Turkey, north of Rhodes. An early site of 'temple-healing' (see TEMPLE MEDICINE) is found in Asklepieia, dedicated to *Aesculapius. Cos was also the birthplace of *Hippocrates c. $560 \mathrm{BC}$. 
BROCA, PAUL (1824-80). French surgeon and anthropologist. He was a pioneer of *orthopaedics as well as *neurosurgery. In 1861 he showed that the left inferior frontal cerebral convolution (Broca's gyrus) was related to speech. He was one of the first to localize and *trephine for *brain abscess.

Lemmata such as these are only found in GPDs with an encyclopedic bias.

\section{Conclusion}

GPDs deal with the general signification of lexical items, while LSPDs are more technical, more specific in their treatment of meaning. The object of definition in both GPDs and LSPDs is not only a concept taken from the field of a special science but also a situation, the analysis of which does not demand expert knowledge and may be limited to separating the various moments or contexts succeeding one another in a specific situation (Doroszewski 1973). Definition is the ability to imagine vividly such an object or a situation and to transpose clearly this image into words. LSP or specialized dictionaries are different from and must be distinguished from limited dictionaries or restricted dictionaries even if they share some features. Where GPDs deal with more than one meaning, LSPDs are usually focused on only one unambiguous meaning. As far as dictionary functions are concerned, LSPDs contain both knowledge- and communication-directed functions within several dictionary articles.

\section{Bibliography}

Al-Kasimi, A.M. 1977. Linguistics and Bilingual Dictionaries. Leiden: Brill.

Bergenholtz, H. and S. Tarp (Eds.). 1995. Manual of Specialised Lexicography. Amsterdam: John Benjamins.

Bergenholtz, H., S. Tarp and H.E. Wiegand. 1999. Datendistributionsstrukturen, Makro- und Mikrostrukturen in neueren Fachwörterbüchern. Hoffman, L., H. Kalverkämper and H.E Wiegand (Eds.). 1999. Fachsprachen. Ein internationales Handbuch zur Fachsprachenforschung und Terminologiewissenschaft/Languages for Special Purposes. An International Handbook of SpecialLanguage and Terminology Research: 1762-1832. Berlin: De Gruyter.

Bird, Roger (Ed.). 19837. Osborn's Concise Law Dictionary. London: Sweet and Maxwell.

Brown, Lesley. 1993. The New Shorter Oxford English Dictionary on Historical Principles. 2 volumes. Oxford: Clarendon Press.

Burkhanov, I. 1998. Lexicography: A Dictionary of Basic Terminology. Rzeszów: Wydawnictwo Wyższej Szkoły Pedagogicznej.

Chambers. 1998. The Chambers Dictionary. London: Chambers.

Coulson, J. et al. (Eds.). 1978. The New Oxford Illustrated Dictionary. Sydney: Bay Books.

Crystal, D. 19972. The Cambridge Encyclopedia of Language. New York: Cambridge University Press.

Doroszewski, Witold. 1973. Elements of Lexicology and Semiotics. The Hague/Paris: Mouton; Warszawa: PWN-Polish Scientific Publishers.

Garner, Bryan A. 19997. Black's Law Dictionary. St. Paul, Minn.: West Group.

Geeraerts, D. 1987. Types of Semantic Information in Dictionaries. Ilson, R. (Ed.). 1987. A Spectrum of Lexicography: Papers from AILA, Brussels 1984: 1-10. Amsterdam: John Benjamins. 
Gläser, Rosemarie. 2000. Should LSP Dictionaries also Include Professional Jargon and Slang? Lexikos 10: 86-98.

Gouws, R.H. 2000. General Theory of Lexicography: An Introduction. Unpublished M.Phil Class Notes. Stellenbosch: University of Stellenbosch, Department of Afrikaans and Dutch and Department of African Languages.

Gouws, R.H. 2003. Using a Frame Structure to Accommodate Cultural Data. Emejelu, J.D. (Ed.). Éléments de lexicographie gabonaise. Tome II: 54-69. New York: Jimacs-Hillman.

Hartmann, R.R.K. 1983. Lexicography: Principles and Practice. London: Academic Press.

Hartmann, R.R.K. and G. James. 1998. Dictionary of Lexicography. London/New York: Routledge.

Hensyl, William R. (Ed.). 199025. Stedman's Medical Dictionary. Baltimore/Hong Kong/London/ Sydney: Williams and Wilkins.

James, John S. 1971. Stroud's Judicial Dictionary of Words and Phrases. London: Sweet and Maxwell.

Lombard, F.J. 2000. Course in General and Computer Lexicography. Unpublished Training Course Notes. Stellenbosch: Bureau of the WAT.

Longman. 1984. Longman Dictionary of the English Language. Harlow, Essex: Longman.

Matthews, P.H. 1997. The Concise Oxford Dictionary of Linguistics. Oxford/New York: Oxford University Press.

Mertvago, P. 1996. Dictionary of 1000 French Proverbs. New York: Hippocerne Books.

Milne, Alexander, Clifford Cooper and Brian D. Burne. 19513. Bell's South African Legal Dictionary. Durban: Butterworth.

Robinson, Mairi (Ed.-in-chief). 1999. Chambers 21st Century Dictionary. Edinburgh: Chambers.

Singh, R.A. 1982. An Introduction to Lexicography. Mysore: Central Institute of India Languages (C.I.I.L).

Smit, M. 1996. Wiegand's Metalexicography as a Framework for a Multilingual, Multicultural, Explanatory Music Education Dictionary for South Africa. Unpublished D.Litt. Thesis. Stellenbosch: University of Stellenbosch.

Smit, M. 2000. Using Frames in Special-Field Lexicography: An Ethnomusicological Case Study. Lexikos 10: 173-188.

Svensén, Bo. 1993. Practical Lexicography: Principles and Methods of Dictionary-Making. Oxford/New York: Oxford University Press.

Tarp, Sven. 2000. Theoretical Challenges to LSP Lexicography. Lexikos 10: 189-208.

Thomas, Clayton L. 197713. Taber's Cyclopedic Medical Dictionary. Philadelphia: F.A. Davis.

Van Schalkwyk, D.J. 1987. Professional Terminology in African Languages: Theory and Practice. $\log 0 \mathrm{~s}$ 7(2): 9-12.

Walton, John, Jeremiah A. Barondess and Stephen Lock (Eds.). 1994. The Oxford Medical Companion. Oxford/New York/Tokyo: Oxford University Press.

Wiegand, H.E. 1983. Ansätze zu einer allgemeinen Theorie der Lexikographie. Schildt, J. and D. Viehweger. 1983. Die Lexikographie von heute und das Wörterbuch von morgen: Analysen - Probleme - Vorschläge: 92-127. Berlin: Akademie der Wissenschaften der DDR, Zentralinstitut für Sprachwissenschaft.

Wiegand, H.E. 1992. Elements of a Theory towards a So-called Lexicographic Definition. Lexicographica 8: 175-289.

Wiegand, H.E. 1994. Zur Unterscheidung von semantischen und enzyklopädischen Daten in Fachwörterbüchern. Schaeder, B. and H. Bergenholtz (Eds.). 1994. Fachlexikographie. Fachwissen und seine Repräsentation in Wörterbüchern: 103-132. Tübingen: Narr.

Wiegand, H.E. 1998. Wörterbuchforschung. Untersuchungen zur Wörterbuchbenutzung, zur Theorie, Geschichte, Kritik und Automatisierung der Lexikographie. 1. Teilband. Berlin: De Gruyter. 